\title{
ABBREVIATIONS AND ARCHIVES CONSULTED
}

Most primary sources for this history are located in the archives of Notre Dame of Maryland University, currently held in Archives and Special Collections at the Loyola Notre Dame Library. Because these sources were originally consulted before the archives were moved and recataloged, they are cited not by box and folder number, but by title and date along with the designation "NDMA" (Notre Dame of Maryland Archives) and, in some cases, an indication of subcollection.

AAU

AAUP

ABA

ASEUT

BMEP

BOSO

Chron.

CND

HEFA

MSA

NDM Catalog

NDMA

OES

OHP

PFA

PM

POAU
Association of American Universities

American Association of University Professors

Archives of the Archdiocese of Baltimore, Associ-

ated Archives at Saint Mary's Seminary \& University,

Baltimore, MD

American Society for the Extension of University

Teaching

Bridget Marie Engelmeyer Papers, NDMA

Board of Student Organizations, College of Notre

Dame

Annals and Chronicles of Notre Dame, NDMA

College of Notre Dame of Maryland (1895-2011)

Higher Education Facilities Act of 1963

Association of Colleges and Secondary Schools of

the Middle States and Maryland (later Middle States

Association of Colleges and Schools)

Catalogs of the College of Notre Dame

Archives of Notre Dame of Maryland University

Oxford Extension Society

Oral History Project, NDMA

Parents and Friends Association, College of Notre

Dame

Patricia Murphy, SSND

Protestants and Other Americans United for

Separation of Church and State 
$\mathrm{RC}$

"Reminiscences of Notre Dame" Collection, NDMA

SJ Society of Jesus (Jesuits)

SSND

\section{Student Publications}

Arras (yearbook)

Columns (newspaper)

Damozel (literary magazine)

A full bibliography for this book can be found at cornellpress.cornell.edu/ book/9781501753794/pursuing-truth/. 